\title{
PENGARUH SELF-EFFICACY TERHADAP RESILIENSI PADA ANGGOTA RESIMEN MAHASISWA
}

\author{
Muhammad Valixe Burhani, \\ Yahya \\ Fakultas Psikologi \\ Universitas Islam Negeri (UIN) Maulana Malik Ibrahim Malang
}

\begin{abstract}
Abstrak - Tujuan penelitian ini adalah untuk mengetahui pengaruh self-efficacy terhadap resiliensi pada anggota Resimen Mahasiswa Mahasurya Jawa Timur angkatan LXVII tahun 2014. Penelitian ini termasuk dalam penelitian kuantitatif. Dalam pengumpulan data, peneliti menggunakan skala CD-RISC untuk mengukur variabel resiliensi sedangkan variabel self-efficacy diukur dengan skala yang dibuat oleh peneliti berdasarkan kajian teori yang ada. Populasi dalam penelitian ini adalah Menwa aktif di lingkungan Resimen Mahasiswa Mahasurya Jawa timur tahun 2014 yaitu berjumlah 343 yang kemudian diambil sebagai sampel dengan menggunakan purposive sampling atau sampel bertujuan dengan mengambil 50 orang. Hasil dari penelitian yang dilakukan adalah bahwa ada pengaruh yang positif atau signifikan maka ( $F$ hitung $=6,202>F$ tabel $=4,03$ ) antara self-efficacy dengan resiliensi. Pengaruh self-efficacy terhadap resiliensi pada anggota Menwa sebesar $11,4 \%$ sedangkan sisanya $88,6 \%$ dipengaruhi oleh faktor lain.
\end{abstract}

Kata Kunci: Self-Efficacy, Resiliensi

PSIKOISLAMIKA. Jurnal Psikologi Islam (JPI) copyright @ 2014 Laboratorium Penelitian, Kajian Psikologi Islam dan Penerbitan. Volume 11. Nomor 2, Tahun 2014

\section{PENDAHULUAN}

Pada dasarnya anggota Resimen Mahasiswa (Menwa) berada pada tahap perkembangan akhir masa remaja dan awal dewasa. Banyak berbagai permasalahan dan kondisi sulit pada tahap perkembangan ini. Tidak jarang permasalahan dan kondisi sulit mendatangkan kondisi yang menekan (adversity) dimana dapat menimbulkan dampak negatif baik fisik maupun psikis. Masalah dalam kehidupan merupakan suatu hal yang akan selalu ada dalam rentang kehidupan manusia. Jika tidak mampu mengatasi permasalahan, maka akan menghambat tahapan perkembangan selanjutnya. Hal ini dijelaskan oleh Erikson (dalam Santrock, 1995) bahwa setiap tahapan perkembangan dalam rentang kehidupan manusia mempunyai tugas perkembangan yang khas yang menghadapkan manusia pada suatu krisis yang harus dihadapi. Semakin individu berhasil mengatasi krisis yang dihadapi maka akan semakin meningkatkan potensi individu dalam rangka menghadapi tahapan perkembangan selanjutnya.

Resimen Mahasiswa memiliki tugas utama dan tugas pokok yang jika tidak dapat dilaksanakan dengan baik maka akan menimbulkan permasalahan. Bagi anggota Resimen Mahasiswa yang tidak dapat beradaptasi dengan baik sering mengalami stres. Sebagai akibatnya anggota Menwa tersebut akan mengalami persoalan di bidang akademik dan langsung berdampak pada performa akademik dimana ditandai dengan waktu studi yang molor, nilai yang rendah, bahkan adapula yang mengalami drop-out. Adapun tugas utamanya yaitu belajar dan menyelesaikan studi sehingga menjadi sarjana yang intelek dan tugas pokoknya antara lain: (1) Melaksanakan Tri Dharma Perguruan Tinggi serta membantu terlaksananya kegiatan dan program lainnya di Perguruan Tinggi; (2) Merencanakan, mempersiapkan dan menyusun seluruh potensi mahasiswa untuk memantapkan ketahanan nasional, dengan melaksanakan usaha 
dan atau kegiatan bela negara; (3) Membantu terwujudnya penyelenggaraan fungsi perlindungan masyarakat (LINMAS), khususnya Penanggulangan Bencana dan Pengungsi (PBP); (4) Membantu terlaksananya kesadaran bela negara dan wawasan kebangsaan dalam organisasi kepemudaan.

Selain masalah di atas, permasalahan yang sering dihadapi setiap anggota Resimen Mahasiswa tidak berbeda jauh dengan mahasiswa pada umumnya. Permasalahan tersebut lebih kepada rasa takut akan kegagalan dalam mencapai kehidupan yang sukses yang seringkali menjadi alasan munculnya stres dan depresi. Selain itu tekanan dari bidang akademis, harapan mendapatkan pekerjaan yang layak dan mapan secara ekonomi merupakan suatu hal yang sangat berpengaruh pada sebagian besar mahasiswa.

Berdasarkan hasil penelitian Saepuddin (2001) setidaknya ditemukan lima kategori permasalahan menonjol yang sering dihadapi mahasiswa yaitu: (1) Pendidikan dan Pengajaran (PDP), yaitu pada aspek penyelesaian tugas-tugas perkuliahan dan kekhawatiran memperoleh nilai rendah dalam ujian ataupun tugas masing-masing; (2) karir dan pekerjaan (KDP), yaitu pada aspek kelemahan memahami bakat dan pekerjaan yang akan dimasuki; (3) Diri Pribadi (DPI), yaitu pada aspek rendah diri atau kurang percaya diri dan aspek kecerobohan atau kekuranghati-hatian; (4) Ekonomi dan Keuangan (EDK), yaitu pada aspek kurang mampu berhemat atau kemampuan keuangan sangat tidak mencukupi, baik untuk keperluan sehari-hari maupun keperluan pelajaran dengan skor, dan (5) Agama, Nilai dan Moralitas (ANM), yaitu pada aspek kemampuan melaksanakan tuntutan keagamaan dan atau khawatir tidak mampu menghindari larangan yang ditentukan oleh agama.

Perasaan jenuh (burnout) juga merupakan hal yang sering terjadi dimana mahasiswa merasa tidak berdaya dan putus asa menghadapi masalah diakibatkan stres yang berlarut-larut. Burnout, menurut Garden (dalam Santrock, 2005) bahwa biasanya bukan terjadi karena satu atau dua kejadian yang traumatis atau menekan akan tetapi merupakan akumulasi bertahap dari beberapa tekanan yang berat. Untuk mengatasi permasalahan hidup maka individu perlu melakukan proses adaptasi. Dalam beradaptasi, ada orang yang mampu bertahan dan pulih kembali dari situasi yang negatif sedangkan ada juga yang gagal karena tidak dapat menghadapi perubahan yang ada. Hal ini tergantung seberapa jauh kemampuan individu menyesuaikan diri terhadap perubahan yang terjadi dalam kehidupan. Secara istilah kemampuan atau kapasitas insani yang dimiliki seseorang, kelompok masyarakat yang memungkinkan untuk menghadapi, mencegah, meminimalkan dan bahkan merubah kondisi yang menyengsarakan menjadi suatu hal yang wajar untuk diatasi disebut resiliensi.

Untuk menunjang pelaksanaan tugas, maka setiap anggota Menwa diwajibkan mengikuti pendidikan dan latihan dasar. Pendidikan dan latihan dasar adalah pendidikan jenjang pertama yang bertujuan membentuk pribadi yang memiliki sikap, disiplin, mental, kemampuan fisik, pengetahuan dan keterampilan dasar, sebagaimana yang dipersyaratkan, agar mampu melaksanakan tugas dan fungsi Resimen Mahasiswa sesuai dengan Panca Dharma Satya Resimen Mahasiswa. Resimen Mahasiswa diberikan bekal ilmu pengetahuan dan penanaman falsafah hidup "penyempurnaan tugas kehidupan dengan ilmu pengetahuan dan ilmu keprajuritari" yang dikenal dengan Widya Castrena Dharma Siddha. Ini diambil sebagai suatu proses untuk melestarikan jiwa patriotisme yang dilakukan oleh para pelajar di perang kemerdekaan: Brigade 17 TP-TRIP.

Dalam kegiatan ini, setiap anggota Menwa baru akan ditempa baik fisik maupun mental dengan sistem semi militer yang berat dan berdisplin tinggi. Setelah terbiasa dihadapkan pada kondisi yang menekan diharapkan setiap anggota menwa memilliki resiliensi yang tinggi pada level berkembang pesat (thriving). Coulson (2006) mengemukakan empat proses yang dapat terjadi ketika seseorang mengalami situasi cukup menekan (significant adversity), yaitu succumbing, survival, recovery, dan thriving. Akhirnya ketika selesai pendidikan dan kembali ke perguruan tinggi akan berdampak baik bagi kehidupan mereka dalam pelaksanaan tugas sehari-hari.

Sebelum melakukan penelitian, peneliti melakukan observasi kegiatan pendidikan dan latihan dasar Resimen Mahasiswa Mahasurya selama 19 hari di Depo Pendidikan Kejuruan (Dodikjur) Rindam V/Brawijaya tahun 2014. Pada saat melaksanakan observasi peneliti melihat banyak sekali kata-kata penggugah keyakinan di dalam lemdik yang terpasang di atas papan yang sering sekali didengungkan di setiap satuan Menwa yaitu ragu-ragu lebih baik kembali dan NKRI harga mati. Secara tidak langsung kata-kata ini memberikan dorongan keyakinan pada setiap calon anggota Menwa baru untuk tidak ragu-ragu dalam menjalankan tugas karena jika ragu-ragu maka lebih baik kembali. 
Kegiatan selama 19 hari dilaksanakan dengan sangat tertib dan disiplin yang berlangsung pukul 05.00 sampai 22.00 WIB. Pendidikan latihan dasar ini terdiri dari 3 tahap proses pencapaian yang diharapkan dapat menjadikan anggota Menwa yang sesuai dengan harapan. Tahap pertama pada minggu pertama para pelatih memberikan materi pelajaran serta lebih menekankan pada perubahan mental para calon anggota Menwa dengan memberikan dorongan keyakinan yang lebih serta sanksi yang berat apabila ada kesalahan serta memberikan tindakan-tindakan fisik yang lebih berat sampai pada akhir minggu pertama. Pada tahap ini pelatih memberikan sanksi dan tindakan fisik yang sangat berat sebagai contoh: apabila ada yang tertidur atau tidak ikut kegiatan tanpa ada halangan sakit pada saat kegiatan berlangsung maka akan dihukum push up, sikap tobat, lari lapangan dan hukuman berat lainnya pada minggu pertama. Hal ini diharapkan setiap anggota menwa mampu menyadari, yakin dan bertindak arif terhadap setiap kesalahan sekecil apapun yang dilakukannya serta diharapkan mampu fokus dalam menerima pelajaran dengan tidak memikirkan hal lain di luar pendidikan.

Tahap kedua pada minggu kedua para pelatih mengurangi tekanan-tekanan yang diberikan, kemudian pelatih lebih fokus pada pemberian materi setelah diberikan tekanan-tekanan dan motivasi pada minggu awal. Pada tahap ini setiap anggota menwa sudah mampu fokus terhadap semua materi yang disampaikan sehingga diharapkan setiap materi dapat terserap dengan baik. Tahap ketiga pada minggu terakhir pelatih memberikan materi praktek sesuai dengan materi yang telah disampaikan pada minggu pertama dan kedua. Pada tahap akhir ini setelah diberikan tekanan pada minggu awal dan diberikan motivasi serta materi di minggu kedua maka diharapkan setiap anggota menwa mampu bertahan dengan baik terhadap tekanan berat yang kemudian dikenal dengan kemampuan untuk resilien.

Dalam kegiatan pendidikan terdapat materi pelajaran khusus yang wajib dikuasi perorangan sebagai contoh materi Niksarpur, Survival dan kemampuan menembak. Beberapa materi khusus tersebut pelatih memberikan pemahaman bahwa jika tidak mampu yakin terhadap kemampuan diri sendiri dan fokus maka materi tersebut tidak akan dapat dikuasai secara maksimal sehingga pada pengaplikasiannya tidak dapat berjalan dengan baik. Oleh karena itu setiap anggota Menwa diharapkan memiliki keyakinan diri yang tinggi yang setiap saat dapat muncul dalam keadaan, situasi dan kondisi yang bagaiamanapun. Keyakinan yang muncul pada diri inilah yang kemudian disebut efikasi diri (self-efficacy).

Selanjutnya latihan-latihan khusus tersebut dipraktekkan pada latihan berganda. Latihan berganda adalah praktek dari seluruh materi yang bersifat praktek, latihan ini bertujuan memberikan bekal pengetahun tentang bagaimana bertahan hidup di alam bebas dalam keadaan yang serba terbatas. Kehidupan di alam bebas tentunya tidak semudah kehidupan sebelumnya ketika masih dilembaga pendidikan. Pada kegiatan ini diharapkan setiap anggota menwa mampu mengaplikasikan segala ilmu yang didapatkan di lembaga pendidikan terutama ilmu bertahan hidup (survival). Tanpa keyakinan diri yang kuat tentunya tidak akan mampu mengaplikasikan ilmu dengan baik serta bertahan hidup di medan yang sulit.

Setelah mengalami pembiasaan kehidupan keprajuritan yang sulit inilah kemudian menggiring setiap anggota Menwa pada kemampuan khusus yaitu memiliki keyakinan bahwa segala sesuatu dapat diselesaikan walaupun dalam keadaan yang sulit dan pada akhirnya mampu bertahan dalam kondisi atau situasi yang sulit. Dari observasi yang peneliti lakukan mendapat hasil sementara bahwa keyakinan diri yang ditanamkan oleh pelatih pada setiap anggota menwa mampu membantu menyelesaikan setiap permasalahan yang terjadi sehingga setiap anggota menwa mampu bertahan dalam keadaan dan kondisi yang sesulit apapun. Hal ini diharapkan ketika kembali pada satuan masingmasing dapat membantu mengurangi permasalahan di kuliah maupun organisasi dengan memiliki keyakinan yang tinggi bahwa segala permasalahan dapat diselesaikan.

Selanjutnya peneliti melakukan wawancara terhadap 2 orang anggota Menwa aktif yang mempunyai faktor resiko yaitu mempunyai tingkat ekonomi rendah. Berdasarkan hasil pengamatan , kedua responden ini mampu beradaptasi secara positif terhadap segala permasalahan hidupnya. Hal ini dibuktikan dengan beberapa prestasi yang didapatkan antara lain: mendapatkan gelar juara pada setiap acara kegiatan Menwa, mendapatkan beasiswa, dan menjadi orang penting diberbagai organisasi selain Menwa. Berdasarkan hasil wawancara dengan kedua responden ini memiliki self-efficacy yang cukup tinggi selain itu terdapat pula karakteristik lain yang mendukung kemampuan beradaptasi secara positif yaitu: kejelasan tujuan hidup, ilmu 
pengetahuan dan memiliki pergaulan yang cukup luas serta optimis dalam mencapai tujuan.

Peneliti juga mengambil data personil mulai angkatan 2007-2010 di salah satu satuan Menwa di Malang. Dari 30 orang anggota di dapatkan hasil 1 orang lulus 7 semester, 14 orang lulus 8 semester, 5 orang lulus 9 semester, 3 orang masih aktif dan yang tidak aktif ada 7 orang. Hasil ini cukup signifikan membuktikan tingkat resiliensi yang cukup tinggi bahwa sebagian besar anggota Menwa tersebut dapat lulus menyelesaikan studinya dengan baik.

Dalam hal ini para ahli psikologi banyak membahas dan tertarik dengan hal-hal yang terkait dengan kualitas individu yang mampu berkembang secara positif meskipun dalam keadaan menekan dalam situasi yang sulit. Dalam hal ini studi resiliensi membahas dan mencoba mencari penjelasan mengapa sebagian individu menunjukkan kemampuan beradaptasi secara positif pada konteks keadaan yang menekan dan terdapat individu yang tidak mampu menghadapinya sehingga terjebak pada perilaku yang patologis.

Kemampuan resiliensi dijelaskan menurut Grotberg (dalam Fonny, dkk, 2006) bahwa resiliensi sangat penting dalam membantu individu untuk mengatasi segala kesulitan yang muncul setiap hari. Jika resiliensi meningkat maka individu akan mampu untuk mengatasi kesulitan apapun yang muncul didalam kehidupan. Individu dengan resiliensi yang baik akan mampu menghadapi masalah dengan baik, mampu mengontrol diri dan mampu mengelola stres dengan baik dengan cara mengubah cara berpikir ketika berhadapan dengan masalah.

Dijelaskan oleh Werner (2005) bahwa banyak faktor yang berkontribusi terhadap resiliensi seseorang antara lain: regulasi emosi, impulse control, optimism, empati, dukungan keluarga, hubungan sosial yang baik, self-esteem, self-efficacy. Rutter dalam (dalam Axford, 2007) mengidentifikasi beberapa kualitas personal yang berkontribusi pada resiliensi seseorang, antara lain kemampuan beradaptasi pada suatu keadaan, mengembangkan ketahanan dari stresor yang ada, berorientasi pada tujuan, pencarian dukungan dari orang lain, rasa humor (sense of humor) dan efikasi diri (selfefficacy). Reivich \& Shutte (dalam Kurniawan, 2008) mengungkapkan beberapa kemampuan yang menyumbang pada resiliensi individu yaitu: regulasi emosi, pengendalian, dorongan, optimism, analisis kausal, empati, kemampuan utnuk meraih apa yang diinginkan, dan efikasi diri.
Efikasi diri seseorang memiliki efek utama terhadap perilaku individu tersebut salah satunya adalah motivasi. Individu dengan efikasi diri yang tinggi mengerahkan usaha yang lebih besar. Bandura mendefinisikan self-efficacy sebagai keyakinan manusia pada kemampuan mereka untuk melatih sejumlah ukuran pengendalian terhadap fungsi diri mereka dan kejadian-kejadian di lingkungannya, dan ia juga yakin kalau self-efficacy adalah fondasi keagenan manusia. Bandura menjelaskan bahwa selfefficacy merupakan salah satu elemen yang sangat penting terhadap resiliensi seseorang. Self-efficacy adalah keyakinan individu atas kemampuannya untuk mengorganisir dan mengambil langkah dalam menyelesaikan masalah atau tugas tertentu.

Self-efficacy merupakan salah satu karakteristik individu yang berhubungan dengan resiliensi. Rutter (dalam Axford) menyatakan bahwa semakin tinggi self-efficacy pada individu, maka semakin mampu individu tersebut untuk beradaptasi terhadap tantangan dan tekanan hidup. Roberts (2007) yang melakukan penelitian pada pemuda (19-22 tahun) pada komunitas militer yang berjumlah 700 orang sebagai partisipannya. Menemukan bahwa selfefficacy sangat berkontribusi pada resiliensi para pemuda yang menjadi partisipannya.

Berdasarkan penjelasan diatas peneliti tertarik untuk mengambil penelitian atas dasar pentingnya efikasi diri individu terhadap resiliensi. Individu yang percaya bahwa segala permasalahan dapat diselesaikan akan mampu beradaptasi secara positif terhadap segala permasalahan. Dengan efikasi diri yang baik diharapkan individu dapat berfungsi lebih baik dalam kehidupannya, terutama bagi anggota Menwa. Peneliti mengambil batasan lebih pada bagaimana setiap anggota Menwa mampu meyakini bahwa setiap kesulitan pasti terdapat jalan keluarnya dan kemampuan dalam beradaptasi secara positif terhadap berbagai permasalahan yang ada. Maka dari itu peneliti ingin meneliti tentang bagaimana pengaruh efikasi diri terhadap resiliensi setelah mengikuti pendidikan dasar dengan mengambil studi kasus pada Mahasiswa yang mengikuti organisasi Resimen Mahasiswa di lingkungan Mahasurya Jawa Timur.

\section{KERANGKA KERJA TEORITIK Resiliensi}

Dalam wacana lingusitik, secara sederhana kita bisa memahami resiliensi dari kamus bahasa Inggris. Echols dan Shadily, misalnya, memiliki definisi bahasa dan menyebut resiliensi, dalam bahasa Inggris, 
sebagai kata "resilience' yang artinya daya pegas, daya kenyal atau kegembiraan. Pengertian Echols dan Shadily ini juga memiliki kemiripan dengan penjelasan Lazarus yang menganalogikan resiliensi seperti sebuah sifat kelenturan pada logam. Misalnya, besi cetak yang banyak mengandung karbon sangat keras tetapi juga memiliki bekal dan sifat getas, mudah patah; tidak resilien. Berkebalikan dengan itu, besi tempa yang memilki kadar karbon yang sedikit memiliki karakteristik yang lunak, mudah dibentuk sesuai dengan kebutuhan; resilien.

\section{Self-Efficacy}

Teori efikasi diri berasal dari "Teori Belajar Sosial" seorang peneliti bernama Bandura. Bandura menjelaskan "Perceived self efficacy refers to beliefs in one's capabilities to organize and execute the course of action required to produce given attainments". Self-efficacy atau efikasi diri merupakan persepsi individu akan keyakinan kemampuannya melakukan tindakan yang diharapkan. Keyakinan efikasi diri mempengaruhi pilihan tindakan yang akan dilakukan, besarnya usaha dan ketahanan ketika berhadapan dengan hambatan atau kesulitan. Individu dengan efikasi diri tinggi memilih melakukan usaha lebih besar dan pantang menyerah.

Menurut Bandura self-efficacy adalah persepsi diri sendiri mengenai seberapa bagus diri dapat berfungsi dalam situasi tertentu. Self-efficacy berhubungan dengan keyakinan diri memiliki kemampuan melakukan tindakan yang diharapkan. Self-efiicacy adalah penilian diri, apakah dapat melakukan tindakan yang baik atau buruk, tepat atau salah, bisa atau tidak bisa mengerjakan sesuai dengan persyaratan. Self-efficacy berbeda dengan aspirasi (cita-cita), karena cita-cita menggambarkan sesuatu yang ideal yang seharusnya (dapat dicapai), sedangkan self-efficacy menggambarkan penilaian kemampuan diri.

\section{METODE}

Tujuan penelitian ini adalah untuk mengetahui pengaruh self-efficacy terhadap resiliensi pada anggota Resimen Mahasiswa Mahasurya Jawa Timur angkatan LXVII tahun 2014. Penelitian ini termasuk dalam penelitian kuantitatif. Dalam pengumpulan data, peneliti menggunakan skala CD-RISC untuk mengukur variable resiliensi sedangkan variabel self-efficacy diukur dengan skala yang dibuat oleh peneliti berdasarkan dengan kajian teori yang ada Populasi dalam penelitian ini adalah Menwa aktif di lingkungan Resimen Mahasiswa Mahasurya Jawa timur tahun 2014 yaitu berjumlah 343 yang kemudian diambil sebagai sampel dengan menggunakan purposive sample atau sampel bertujuan dengan mengambil 50 orang. Sesuatu yang ideal yang seharusnya (dapat dicapai), sedangkan self-efficacy menggambarkan penilaian kemampuan diri.

\section{HASIL PENELITIAN}

Hasil penelitian mendapatkan bahwa selfefficacy pada anggota angkatan LXVII Menwa Mahasurya Jawa Timur dibagi menjadi tiga kategori yaitu tinggi, sedang, dan rendah. Dalam distribusi kategori tinggi terletak pada self-efficacy anggota Menwa yang memiliki persentase sebesar 18,0\% diperoleh 9 orang dari 50 responden, sedangkan untuk kategori sedang sebesar 60,0\% diperoleh 30 orang dari 50 responden, dan untuk kategori rendah sebesar $22,0 \%$ diperoleh 11 orang dari 50 responden. Sedangkan untuk tingkat resiliensi pada anggota Menwa Mahasurya Jawa Timur dibagi menjadi tiga kategori yaitu tinggi, sedang, dan rendah. Dalam distribusi kategori tinggi terletak pada resiliensi anggota Menwa yang memiliki persentase sebesar $14,0 \%$ diperoleh 7 orang dari 50 responden, sedangkan untuk kategori sedang sebesar $76,0 \%$ diperoleh 38 orang dari 50 responden, dan untuk kategori rendah sebesar $10,0 \%$ diperoleh 5 orang dari 50 responden.

Hasil penelitian terkait klasifikasi tinggi dan rendahnya self-efficacy individu sangat dipengaruhi oleh kualitas individu dalam mengatasi segala masalah yang di hadapi dalam kehidupannya. Individu yang memiliki self-efficacy tinggi dalam mengerjakan suatu tugas tertentu akan cenderung memilih terlibat langsung sekalipun tugas tersebut dirasa sulit untuk diselesaikan. Mereka tidak memandang tugas sebagai suatu ancaman yang harus mereka hindari. Selain itu, mereka mengembangkan minat instrinsik dan ketertarikan yang mendalam terhadap suatu aktivitas, mengembangkan tujuan, dan berkomitmen dalam mencapai tujuan tersebut. Mereka juga meningkatkan usaha mereka dalam mencegah kegagalan yang mungkin timbul. Mereka yang gagal dalam melaksanakan sesuatu, biasanya cepat mendapatkan kembali self-efficacy mereka setelah mengalami kegagalan tersebut. Berlaku sebaliknya terhadap individu yang memiliki selfefficacy rendah. Mereka akan menjauhi tugas-tugas yang sulit karena tugas tersebut dipandang sebagai ancaman bagi mereka. Individu yang seperti ini memiliki asprasi yang rendah serta komitmen yang rendah dalam mencapai tujuan yang mereka 
pilih atau mereka tetapkan. Ketika menghadapi tugas-tugas yang sulit, mereka sibuk memikirkan kekurangan-kekurangan diri mereka, gangguangangguan yang mereka hadapi, dan semua hasil yang dapat merugikan mereka. Dalam mengerjakan suatu tugas, individu yang memiliki self-efficacy rendah cenderung menghindari tugas tersebut (Bandura, 1997).

Selanjutnya dari hasil analisa data di atas, maka didapatkan hasil yang signifikan bahwa selfefficacy berpengaruh pada resiliensi seseorangyang kemudian dapat memperkuat penelitian-penelitian sebelumnya. Hasil analisa data menunjukkan bahwa self-efficacy mempunyai pengaruh terhadap resiliensi anggota angkatan LVII Menwa Mahasurya Jawa Timur atau dengan kata lain/ / a diterima dan $\mathrm{HO}$ ditolak. Selanjutnya Nilai Fhitung dari hasil analisa regresi menunjukkan nilai sebesar 6,202 dimana lebih besar dari Ftabel sebesar 4,03. Pengaruh dari self-efficacy terhadap resiliensi anggota Menwa Mahasurya Jawa Timur juga signifikan dengan ditunjukkan nilai signifikan sebesar 0,000 yang lebih kecil dari taraf kepercayaan yang digunakan peneliti yaitu sebesar $5 \%(0,05)$. Hal ini dibuktikan dengan penelitian yang dilakukan oleh Roberts (2007) yang menemukan bahwa self-efficacy mempunyai pengaruh penting terhadap resiliensi seseorang.

Dijelaskan dari hasil analisa regresi bahwa koefisien diterminasi yang ditunjukkan oeh nilai $R$ Square sebesar 0,114 dengan adjusted R Square 0,096. Dengan nilai determinasi 0,114 mengindikasikan bahwa 11,4\% self-efficacy berkontribusi pada resiliensi anggota Menwa, sedangkan sisanya 88,6\% dipengaruhi oleh faktor lain.

Atribut individu berkaitan dengan kualitas individu dalam menghadapi permasalahan dalam hidupnya. Kualitas individu sangat menentukan apakah individu tersebut mampu beradaptasi secara positif terhadap tekanan atau tidak. Atribut individu ini dalam kajian resiliensi dalam Connor \& Davidson (2003) antara lain kemampuan intelegensi, self-efficacy, kepercayaan diri, regulasi emosi, self-esteem, selera humor, problem solving, optimism, tujuan hidup, empati, analisis kausal, internal locus of control, kemampuan untuk meraih apa yang diinginkan dan kualitas individu lainnya. Pada penelitian ditemukan bahwa self-efficacy berpengaruh cukup signifikan terhadap resiliensi individu yaitu $11,4 \%$.

Kedua faktor berikutnya merupakan aspek eksternal yaitu faktor keluarga dan lingkungan sosial. Menurut Bandura kedua faktor ini merupakan faktor lingkungan yaitu lingkungan keluarga dan lingkungan social. Faktor-faktor ini antara lain yaitu status ekonomi, status sosial, pola asuh, persahabatan, dan faktor-faktor lingkungan lainnya.

\section{KESIMPULAN}

Dari hasil penelitian ini didapatkan perhitungan analisis regresi yaitu nilai konstanta sebesar 36,869 koefisien efikasi diri 0,146. Dengan demikian didapatkan persamaan garis regresi $\mathrm{Y}=\mathrm{a}+\mathrm{bx}$ $=36,869+(0,146)$. Persamaan regresi tersebut menunjukkan bahwa jika skor efikasi diri sebesar nol, maka skor resiliensi sebesar 36,869 . Selain itu dapat diprediksikan bahwa jika terdapat perubahan pada skor efikasi diri sebesar satu dapat mempengaruhi perubahan resiliensi rata-rata sebesar 0,146 . Selanjutnya koefisien diterminasi yang ditunjukkan oleh nilai R Square sebesar 0,114 dengan adjusted R Square 0,096. Dengan nilai determinasi 0,114 mengindikasikan bahwa 11,4\% self-efficacy berkontribusi pada resiliensi anggota Menwa, sedangkan sisanya $88,6 \%$ dipengaruhi oleh faktor lain.

\section{DAFTAR PUSTAKA}

Axford, K. M. 2007. Attachment, Affect Regulation, and Resilience Students. Disertation, Walden University.

Bandura, A. 1997. Self-Efficacy, The Exercise of Kontrol. W.H. Freeman and Company, New York.

Bandura, A. 1977. Self-Efficacy: Toward a Unififying Theory of Behavioral Chance. Psychological Review, Vol. 84, No. 2. 197.

Connor M, Kathryn, M.D and Davidson R.T, Jonthan, M.D. 2003. Development of A New Resilience

Scale (CD-RISC). Research Article. Depression and Anxiety 18:76-82.

Coulson, R. 2006. Resilience And Self-Talk In University Students. Thesis University of Calgary.

Echols, J., M. \& Shadily, H. 1976. Kamus Inggris Indonesia. PT. Gramedia, Jakarta.

Fonny., Waruwu, E.F dan Lianawati. 2006. Resiliensi dan Prestasi Akademik Pada Anak Tuna Rungu. Jurnal Provitae. 2(1): 34-39.

Kurniawan, I., N. \& Vita R. 2008. Pengaruh Pelatihan Resiliensi terhadap Perilaku Asertif pada Remaja. Jurnal Psikologi Islam, Vol. 5, Nomor 


\section{1, 93-105.}

Roberts, K., A. 2007. Self-Efficacy, Self-Concept, and Social Competences as Resources Supporting Resilience and Psychological Weel-Being Young Adults Reared within the Military Community. Dissertation, Fielding Graduate University.

Saepudin, A. 2001. Penataan Program Bimbingan dan Konseling Berdasarkan Permasalahan Mahasiswa dan Harapan Sivitas Akademika: Studi Deskriptif Analitik dalam Rangka Penyusunan Program Bimbingan dan Konseling di Sekolah Tinggi Manajemen Informatika dan Komputer Mandira Indonesia. Abstrak on-line: digilib. upi.edu.
Santrock, J., W .1995. Live Span Development. Jilid I, Terjemahan oleh Chusairi, Edisi ke-5, Penerbit Erlangga Jakarta.

Santrock, J. W. 1995. Live Span Development. Jilid II, Terjemahan oleh Chusairi, Edisi ke-5, Penerbit Erlangga Jakarta.

Werner, Emmy, E. (2005). Resilience Research: Past, Present, and Future. Dalam Peters dkk. Resilience in Children, Families and Community: Linking Context to Practice and Policy. Plenum Publisher, New York. 